\title{
Pemeriksaan Kadar Glukosa Darah Sewaktu, Kadar Asam Urat dan Kadar Cholesterol pada Masyarakat di Desa Eretan Wetan Kabupaten Indramayu Periode Februari 2020
}

\author{
Rospita Adelina Siregar ${ }^{1}$, Adolfina R. Amahorseja ${ }^{2}$, Ance Adriani ${ }^{3}$, Jumaini Andriana ${ }^{4}$ \\ 1,2,3,4, Universitas Kristen Indonesia, Jakarta, Indonesia \\ e-mail: ${ }^{1}$ mapituki@yahoo.co.id, ${ }^{2}$ adolfina.279@gmail.com, ${ }^{3}$ anceadriani10@yahoo.com, \\ ¿umainiandriana@yahoo.com
}

\begin{abstract}
Abstrak
Pelaksanan PkM FKUKI Jakarta berlokasi di kantor kelurahan Desa Eretan Kulon, pada hari Sabtu 22 Februari 2020, diawali dengan "Penyuluhan Pelayanan Kesehatan dan Perlindungan Hukum Kesehatan Reproduksi Perempuan" disampaikan oleh dr.Rospita Adelina Siregar,MH.Kes dengan audiens ibu-ibu/ perempuan berjumlah 150 orang , Feedback yang didapat antara lain masyarakat belum faham atas hak reproduksinya, masyarakat belum faham penerapan hak reproduksinya ,dalam menentukan cara ber-KB, menentukan jumlah anak ,penyebab kemungkinan karena pendidikan rendah, sebagian besar tidak tamat SD. Kegiatan dilanjutkan dengan pengobatan gratis bagi 938 orang, terdiri dari kelompok usia dewasa dan anak, kegiatan ini dilayani oleh tim kesehatan dari FKUKI yaitu:dr.Adolfina R.Amorhorseja,MS: dr.Ance Adriani,MS.Sp.OK.,Sp.GK dan dr.Jumaini Andriana,MPd.Ked. juga pemeriksaan darah bagi 492 orang pasien atas indikasi dilayani oleh tim kesehatan GKJ (PIC.drg.Sri Rahayu dan dr.Sri Udaneni), dengan rincaian : jumlah pasien yang dilakukan pemeriksaan Gula Darah sebanyak 207 orang, Asam Urat 159 orang, serta pemeriksaan kadar Cholesterol 105 orang , Kesimpulan : Kadar Glukosa Sewaktu < 145 mg/dl sejumlah 127 orang $(61,4 \%)$, Kadar Asam Urat $(5-7 \mathrm{mg} / \mathrm{dl})=$ Normal, sejumlah 116 orang $(73 \%)$, serta Kadar Cholesterol $(<200 \mathrm{mg} / \mathrm{dl})=$ Normal, sebanyak 60 orang $(57,1 \%)$.
\end{abstract}

Kata Kunci: Penyuluhan, Pengobatan, Hak Reproduksi, Perempuan

\begin{abstract}
The implementation of PkM FKUKI Jakarta is located in the village office of Eretan Kulon Village, on Saturday, February 22, 2020, beginning with "Counseling Health Services and Legal Protection for Women's Reproductive Health" delivered by dr. Rospita Adelina Siregar, MH.Kes. with an audience of mothers / women numbering 150 people, the feedback obtained included that the community did not understand their reproductive rights, the community did not understand the application of their reproductive rights, in determining the method of family planning, determining the number of children, the probable cause of low education, most did not graduated elementary school. The activity was continued with free treatment for 938 people, consisting of adult and child age groups, this activity was served by a health team from FKUKI, namely: Dr. Adolfina $R$. Afhorseja, MS: Dr. Ance Adriani, MS.Sp.OK., Sp. GK and Dr. Jumaini Andriana, MPd. Ked. also blood tests for 492 patients on the indication served by the GKJ health team (PIC.drg. Sri Rahayu and Dr. Sri Udaneni), with details: the number of patients undergoing Blood Sugar examination as many as 207 people, Uric Acid 159 people, and examination of levels Cholesterol 105 people, Conclusion: When Glucose Levels <145 mg / dl are 127 people (61.4\%), Uric Acid Levels (5-7 $\mathrm{mg} / \mathrm{dl})=$ Normal, 116 people (73\%), and Cholesterol Levels $(<200 \mathrm{mg} / \mathrm{dl})=$ Normal, as many as 60 people (57.1\%).
\end{abstract}

Keywords: Counseling, Treatment, Reproductive Rights, Women. 
Volume 2, Nomor 1, Tahun 2020 Hal 291- 300

\section{PENDAHULUAN}

Pemeriksaan laboratorium klinik adalah salah satu faktor penunjang yang penting dalam membantu menegakkan diagnosis suatu penyakit, salah satunya pemeriksaan glukosa darah. Glukosa darah atau gula darah merupakan gula yang berada dalam darah yang terbentuk dari karbohidrat dalam makanan dan disimpan sebagai glikogen di hati dan otot rangka. Hormon yang mempengaruhi kadar glukosa adalah insulin dan glukagon yang berasal dari pankreas. Nilai rujukan kadar gula darah dalam serum/plasma $70-110 \mathrm{mg} / \mathrm{dl}$, gula dua jam postprandial $\leq 140 \mathrm{mg} / \mathrm{dl} / 2 \mathrm{jam}$, dan gula darah sewaktu $\leq 110 \mathrm{mg} / \mathrm{dl}$. Kadar glukosa darah yang tinggi dapat disebabkan karena adanya beberapa faktor yaitu konsumsi makanan yang tinggi lemak, karbohidrat sederhana dan makanan olahan dengan kurang aktifitas fisik dan olahraga berkaitan dengan peningkatan kadar gula darah.

Diabetes melitus (DM) merupakan sekelompok gangguan metabolik dengan gejala umum hiperglikemia. Penyakit ini merupakan suatu kelompok penyakit metabolik dengan karakteristik hiperglikemia yang terjadi karena kelainan sekresi insulin, kerja insulin, atau keduanya. Beberapa proses patologis terlibat dalam terjadinya diabetes, mulai dari perusakan sel $\beta$ pada pankreas dengan konsekuensi definisi insulin, sampai abnormalitas yang berujung pada resistensi insulin. Glukosa darah memang sangat berhubungan dengan makanan yang di konsumsi oleh seseorang. Jumlah, jenis maupun waktu. Secara umum, gula darah seseorang akan berbeda saat ia bangun tidur, mau tidur atau sedang beraktifitas. Angka gula darah juga akan berubah manakala seseorang melakukan pemeriksaan ini setelah makan. Gula darah sewaktu merupakan salah satu pemeriksaan kimia yang bertujuan untuk screening Diabetes Mellitus sebagai upaya deteksi dini terhadap penyakit ini. Pemeriksaan ini dapat dilakukan dengan menggunakan strip.

Data dari Riset Kesehatan Dasar (RISKESDAS) pada tahun 2013 menunjukkan bahwa proporsi dan perkiraan jumlah diabetes melitus pada penduduk usia $\geq 15$ tahun di Indonesia yaitu berjumlah 12.191 .564 penduduk dengan proporsi $6.9 \%$ dari jumlah penduduk keseluruhan 176.689 .336 penduduk. 
Volume 2, Nomor 1, Tahun 2020 Hal 291- 300

Penyakit gout adalah salah satu tipe dari arthristis (rematik) yang disebabkan terlalu banyaknya atau tidak normalnya kadar asam urat di dalam tubuh karena tubuh tidak bisa mengsekresikan asam urat. secara normal/seimbang. Asam urat merupakan asam yang berbentuk kristal yang merupakan hasil akhir dari metabolisme purin.

Berdasarkan data yang diperoleh dari WHO menyatakan penderita radang sendi di Indonesia mencapai $81 \%$ dari populasi, hanya $24 \%$ yang pergi ke dokter sedangkan $71 \%$ cendrung langsung mengonsumsi obat-obatan peredar nyeri yang di jual bebas. Angka ini menempatkan Indonesia sebagai Negara paling tinggi menderita radang sendi radang sendi jika dibandingkan dengan negara Asia lainnya, seperti Hongkong, Singapura, Malaisya dan Taiwan. Prevalensi penyakit persendian berdasarkan diagnosis nakes tertinggi di Bali (19,3\%) di ikuti oleh Aceh (18,3\%), Jawa Barat $(17,5 \%)$ dan Papua $(15,4 \%)$. Menurut WHO penyakit kardiovaskular adalah penyebab nomor satu kematian secara global. Setiap tahun orang yang meninggal akibat kelainan kardiovaskular lebih banyak dibandingkan karena penyakit lainnya. Salah satu penyakit kardiovaskular ialah penyakit jantung koroner (PJK) yang merupakan gangguan jantung disebabkan oleh menyempitnya pembuluh darah koroner (arteri koronaria) akibat aterosklerosis. Berdasarkan hasil riset kesehatan dasar 2013, prevalensi PJK tertinggi di Indonesia terdapat pada daerah Sulawesi Tengah (0,8\%) diikuti oleh Sulawesi Utara, DKI Jakarta dan Aceh (0,7\%). Cholesterol sering dikaitkan dengan penyakit jantung dan pembuluh darah (kardiovaskular). Kadar cholesterol yang tinggi dalam darah dapat memicu berbagai macam penyakit, diantaranya PJK. Cholesterol secara normal diproduksi oleh tubuh dalam kadar yang cukup, namun sebagian besar cholesterol didapat dari makanan yang dikonsumsi sehari-hari, terutama makanan yang tinggi lemak. Selain faktor makanan, faktor genetik dan usia juga berperan dalam peningkatan kadar cholesterol dalam tubuh.

Rumusan Masalah.

Bagaimana profil kadar glukosa darah, asam urat dan cholesterol pada masyarakat di Desa Eretan Wetan Kabupaten Indramayu pada periode Februari 2020?. 
Tujuan Penelitian.

Mengetahui profil kadar glukosa darah, asam urat dan cholesterol pada masyarakat di Desa Eretan Wetan Kabupaten Indramayu pada periode Februari 2020.

\section{METODE}

Jenis pemeriksaan yang digunakan dalam penelitian ini adalah penelitian desktiptif untuk mengatahui profil atau gambaran kadar glukosa darah sewaktu, kadar asam urat dan cholesterol darah pada masyarakat di Desa Eretan Wetan Kabupaten Indramayu. Penelitian ini telah dilakukan di kantor Kepala Desa Eretan Wetan Kabupaten Indramayu. pada pada 22 Februari 2020, populasi dalam penelitian ini adalah masyarakat di Desa Eretan Wetan yang datang untuk pemeriksaan laboratorium glukosa darah, asam urat dan cholesterol darah..Sampling dilakukan secara tidak acak dengan metode quota sampling.

\section{HASIL DAN PEMBAHASAN}

Tujuan

Pembangunan

berkelanjutan 2030 telah menetapkan target untuk mengurangi angka kematian akibat penyakit tidak menular (termasuk Diabetes), menjadi sepertiganya, agar dapat mencapai Universal Health Coverage (UHC) dan menyediakan akses terhadap obat-obatan esensial yang terjangkau pada tahun 2030.

Secara global, diperkirakan 422 juta orang dewasa hidup dengan Diabetes pada tahun 2014, dibandingkan dengan 108 juta pada tahun 1980. Prevalensi Diabetes di dunia (dengan usia yang distandarisasi) telah meningkat hampir dua kali lipat sejak tahun 1980, meningkat dari 4,7\% menjadi $8,5 \%$ pada populasi orang dewasa. Hal ini mencerminkan peningkatan faktor risiko terkait seperti kelebihan berat badan atau Obesitas.

Diabetes menyebabkan 1,5 juta kematian pada tahun 2012 Gula darah yang lebih tinggi dari batas maksimum mengakibatkan tambahan 2,2 juta kematian, dengan meningkatkan risiko penyakit Kardiovaskular dan lainnya. Empat puluh tiga persen (43\%) dari 3,7 juta kematian ini terjadi sebelum usia 70 tahun. Persentase kematian yang disebabkan oleh Diabetes yang terjadi sebelum usia 70 tahun lebih tinggi di negara negara berpenghasilan rendah dan menengah dari pada di negaranegara berpenghasilan tinggi. (WHO Global Report, 2016). 
Meskipun faktor risikonya sering dikaitkan dengan gaya hidup, namun jumlah kematian akibat penyakit kardiovaskular dan Diabetes cenderung lebih banyak terjadi di negara berkembang dibandingkan dengan negara maju. Jika dibandingkan dengan tahun 2013, prevalensi DM berdasarkan diagnosis dokter pada penduduk umur $\geq$ 15 tahun hasil Riskesdas 2018 meningkat menjadi $2 \%$. Prevalensi DM berdasarkan diagnosis dokter dan usia $\geq$ 15 tahun yang terendah terdapat di Provinsi NTT, yaitu sebesar 0,9\%, sedangkan prevalensi DM tertinggi di Provinsi DKI Jakarta sebesar 3,4\%.

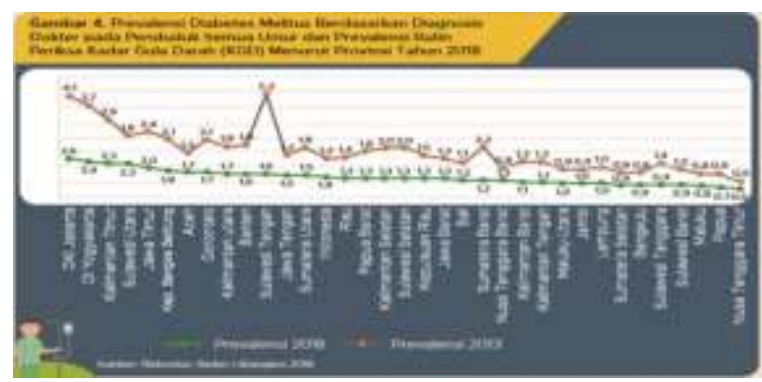

Gambar 1. Prevalensi Diabetes di Indonesia

Prevalensi DM semua umur di Indonesia pada Riskesdas 2018 sedikit lebih rendah dibandingkan prevalensi DM pada usia $\geq 15$ tahun, yaitu sebesar $1,5 \%$. Sedangkan provinsi dengan prevalensi DM tertinggi semua umur berdasarkan diagnosis dokter juga masih di DKI Jakarta dan terendah di NTT.

\begin{tabular}{|c|c|c|}
\hline $\begin{array}{c}\text { Kadar Gula Darah } \\
\text { mg/dl }\end{array}$ & Frekuensi & $\%$ \\
\hline$<145$ & 127 & 61,4 \\
\hline $145-180$ & 22 & 10,6 \\
\hline$>180$ & 58 & 28,0 \\
\hline
\end{tabular}

Tabel 1. Distribusi Frekuensi Kadar Gula Darah Pada Masyarakat di Desa Eretan Wetan Kabupaten Indramayu Periode Februari Tahun 2020.

Pada tabel 1 terlihat dari 207 orang yang dilakukan pemeriksaan glukosa darah sebanyak 127 orang (61.4\%) dan 22 orang $(10,6 \%)$ kadar glukosanya normal, sedangkan 58 orang (28\%) kadar glukosa darahnya tinggi.

Kristal asam urat dapat merusak lapisan bagian dalam pembuluh darah koroner pada jantung. Rusaknya pembuluh darah itu akan menimbulkan serangan jantung koroner. Oleh sebab itu, sebaiknya secara teratur kita harus mengecek kadar asam urat, jika asam uratnya tinggi maka sedini mungkin harus berupaya untuk menurunkannya supaya tidak terjadi kerusakan pada organ-organ penting tubuh kita. Sebagai akibat asam urat, ginjal juga akan mengalami gangguan. Pada kasus yang parah, penderita sampai tidak bisa jalan karena persendian terasa sangat sakit jika bergerak. Tulang di sekitar sendi juga 
Volume 2, Nomor 1, Tahun 2020 Hal 291- 300

bisa keropos / mengalami pengapuran tulang.

Cara penanganan asam urat menurut (Zahara, 2013) Minum air putih yang banyak (minimal 8-10 gelas/hari), Istirahatkan bagian yang sakit untuk beberapa jam, Hindari makanan yang mengandung tinggi purin : daging merah, seafood, anggur, kacang-kacangan, ragi, teh dan kopi, Hindari kecemasan dan cegah terjadinya trauma pada kulit, Olahraga rutin dan kompres hangat kayu manis untuk mengurangi nyeri sendi, Meminum rebusan daun sirsak.

\begin{tabular}{|c|c|c|}
\hline $\begin{array}{c}\text { Asam Urat } \\
\text { Darah } \\
(\mathrm{mg} / \mathrm{dl})\end{array}$ & Freukensi & $\%$ \\
\hline Normal & 116 & 73 \\
\hline Tinggi & 43 & 27 \\
\hline
\end{tabular}

Tabel 2.

Distribusi Freukensi Kadar Asam Urat Pada Masyarakat di Desa Eretan Wetan Kabupaten Indramayu Periode Februari Tahun 2020.

Pada tabel 2 terlihat dari 159 orang yang memeriksa kadar asam urat didapatkan 116 orang (73\%) kadar asam uratnya normal dan 43 orang (27\%) kadar asam uratnya tinggi.

Edukasi dan promosi kesehatan memiliki manfaat yang besar dalam mencegah terjadinya Dislipidemia sekunder. Modifikasi diet rendah Asam Lemak jenuh dan tinggi asam lemak tidak jenuh dapat membantu mencegah terjadinya Dislipidemia. Selain itu, asupan tinggi serat dan menghindari konsumsi gula dan alkohol berlebih dapat menurunkan risiko terjadinya Dislipidemia. Menghentikan kebiasaan merokok menurunkan risiko Kardiovaskular pada pasien Dislipidemia dan menghindarkan terjadinya Aterosklerosis. Aktivitas fisik reguler dengan intensitas sedang seperti jalan cepat 30 menit, berenang selama 20 menit, dan bersepeda dapat bermanfaat. Aktivitas fisik tersebut secara reguler harus dilakukan setidaknya 5 hari dalam satu minggu.

\begin{tabular}{|c|c|c|}
\hline $\begin{array}{c}\text { Cholesterol } \\
\text { Darah } \\
(\mathrm{mg} / \mathrm{dl})\end{array}$ & Freukensi & $\%$ \\
\hline Normal & 60 & 57,10 \\
\hline Tinggi & 45 & 42,90 \\
\hline
\end{tabular}

Tabel 3.

Distribusi Freukensi Kadar Cholesterol Darah Pada Masyarakat di Desa Eretan Wetan Kabupaten Indramayu Periode Februari Tahun 2020.

Pada tabel 3. Terlihat dari 105 orang yang dilakukan pemeriksaan Cholesterol darah, 60 orang $(57,10 \%)$ 
Volume 2, Nomor 1, Tahun 2020 Hal 291- 300

hasil nya normal, dan 45 orang (42.9\%) kadarnya tinggi.

\section{KESIMPULAN}

Hasil dari kegiatan diPkM Desa Eretan Wetan Kabupaten Indramayu pada periode Februari 2020 berkesimpulan, bahwa didapat profil kadar glukosa darah, asam urat dan Cholesterol sebagai berikutnya:

a. Kesan dari 207 orang yang dilakukan pemeriksaan glukosa darah sebanyak 127 orang (61.4\%) normal dan 22 orang $(10,6 \%)$ kadar glukosanya moderate, sedangkan 58 orang (28\%) kadarnya tinggi.

b. Kesan dari 159 orang yang memeriksa kadar asam urat didapatkan 116 orang (73\%) kadar asam uratnya normal dan 43 orang (27\%) kadarnya tinggi.

Kesan dari 105 orang yang dilakukan pemeriksaan Cholesterol darah, 60 orang $(57,10 \%)$ kadar Cholesterol normal, sedangkan 45 orang (42.9\%) kadarnya tinggi.

Masyarakat di desa Eretan Wetan Kabupaten Indramayu memiliki profil gula darah $28 \%$ tinggi hal ini memiliki potensi yang tinggi untuk penyakit Diabetes , munculnya komplikasi dimulai dari terjadinya mikroangiopati sampai makroangiopati dan kerusakan meluas tidak dapat dihindari apabila pasien tidak memiliki pengetahuan tentangg Diabetes yang benar, lalu ditemukan 23\% hiperuremicum yang di khawatirkan akan berlanjutnya terbentuknya batu asam urat, yang akan merusak ginjal juga sakit persendian. Kemudian hasil 42.9\% masyarakat di desa Eretan Wetan merupakan penyakit Dislipidemia sekunder, yang nantinya akan mendorong masuk kedalam kelompok penderita penyakit Cardiovaskuler, seperti : Artherosklerosis, penyakit jantung, dan lain-lainnya.

\section{UCAPAN TERIMA KASIH}

Kami sampaikan kepada pihak yang telah membantu kegiatan PkM FK UKI ini, sebagai berikut:

1. A Haris Fauzi sebagai Lurah desa Eretan Wetan

2. Sudinto Raswad sebagai Sekretaris desa Eretan Wetan

3. Pnt Budhi Santoso sebagai badan pelaksana klasis GKJ klasis Jakarta bagian timur

4. Drg.Sri Rahayu Koordinator Tim Kesehatan klasis GKJ klasis Jakarta bagian timur 
5. Dr Dhaniswara K Harjono, $\mathrm{SH}, \mathrm{MH}$, MBA sebagai Rektor UKI

6. Prof Yovita sebagai Koordinator PkM FKUKI Jakarta.

7. Teman - teman Tim PkM FK UKI Jakarta

\section{REFERENSI}

5 Go AS, Mozzaffarian D, Roger VL. Heart disease and stroke statistic - 2014 update: a report from the american heart association. Circulation. 2014; 129:e28e292.

American Diabetes Association Approaches to Glycemic Treatment Diabetes Care 2013;39:52-9.

American Diabetes Association, Classification and Diagnosis of Diabetes, Diabetes Care 2015; 38:8-16.

Anies.2015, Cholesterol dan penyakit jantung koroner (1st ed). Jogjakarta: Ar-ruz media, Jogjakarta.

Asmak, \& Nazulatul. (2017). Hubungan Asupan Bahan Makanan Sumber Purin, Vitamin C, Dan Cairan Dengan Kadar Asam Urat Pada Pasien Hiperurisemia Rawat Jalan Di Rumah Sakit Roemani Muhammadiyah Semarang. Universitas Muhammadiyah Semarang .
Azwar, Bahri. 2004. Dislipidemia sebagai Faktor Resiko Penyakit Jantung Koroner. FK USU, Medan.

Badan Penelitian dan Pengembangan Kesehatan Kementerian Kesehatan RI. Hasil Riskesdas 2018.

Badan penelitian dan pengembangan kesehatan kementrian kesehatan RI tahun 2013. Laporan nasional riset kesehatan dasar (RISKESDAS) 2013. 2014.

Choirum, F. P., Farida, J., \& Arfian, M. (2015), Hubungan Obesitas Dengan Kadar Asam Urat Darah Di Dusun Pilanggadung Kecamatan Tikung Kabupaten Lamongan.Jurnal Surya, 2(9).

Dewi. et all. 2013. Pengaruh Pemberian Ekstrak Kelopak Bunga Rosella (Hibiscus Sabdariffa) Terhadap Penurunan Kadar Gula Darah Pada Penderita Diabetes Mellitus Tipe li Di Puskesmas Palangka Raya Kalimantan Tengah. Penerbit Sekolah Tinggi IImu Kesehatan Sint Carolus. Jakarta.

Dita Garnita,2012, Faktor Risiko Diabetes Melitus di Indonesia (Analisis Data Sakerti 2007), FKM UI, Jakarta.

Firgiansyah Andi. 2016, Perbandingan Kadar Glukosa Darah menggunakan Spektrofotometer Dan 
Volume 2, Nomor 1, Tahun 2020 Hal 291- 300

Glukometer, Universitas Muhammadiah, Semarang.

Ganiswarna, Sulistia. 2007. Farmakologi dan Terapi. Jakarta: Gaya Baru.

Gregg EW, Li Y, Wang J. Changes in diabetes-related complications in the united states, 1990 - 2010. N Engl J Med. 2014. 370(16): 1514-23.

Grundy SM, Ji Cleeman, Merz CN. Implications of recent clinical trials for the National Cholesterol Education Program Adult Treatment Panel III Guidelines. Circulation 2004;110:227-39.

http://kesga.kemkes.go.id/images/ pedoman/Data\%20Riskesdas\%202013. pdf

International Diabetes Fondation. IDF Diabetes Atlas. $7^{\text {th }}$ ed. IDF 2015. Available at : http://www.idf.org/idfdiabetes-atlas-seventh-edition.

Joyce. 2013. Pedoman Pemeriksaan Laboratorium \& Diagnostik, Edisi 6, EGC, Jakarta.

Kemenkes. (2013). Riset Kesehatan Dasar. Jakarta: Badan Penelitian dan Pengembangan Kesehatan I.

Misnadiarly. 2008. Mengenal Penyakit Arthritis. Mediakom. Edisi I.
Rundy SM, Cleeman JI, Merz CNB. Implications of Recent Clinical Trials for the National Cholesterol Education Program Adult Treatment Panel III Guidelines. Circulation. 2004; 110:22739.

Santulli G. 2013, Epidemiology of cardiovascular disease in the 21st century: updated numbers and update facts. Journal of Cardiovascular Disease. 2013;1:1. 2.

Shahab, Alwi. 2013. Patofisiologi dan Penatalaksanaan Dislipidemia. Available at http://www.dokteralwi.com/dislipidemia files/dislipidemia. html (dikses tanggal 19 maret 2020).

Sholihah, F. M. (2014). Diagnosis And Treatment Gout Arthritis.Majority, $3(07)$.

Siregar, R. A. (2013). Effective Communication Between Doctor and Patient Will Prevent Medical Dispute.

Sudoyo, Ary, Setyohadi, Bambang, Alwi, Idrus. 2009. Buku Ajar Ilmu Penyakit Dalam. Jakarta: FK UI.

Tinah, P. (2010). Faktor-Faktor Risiko Hiperurisemia (Studi Kasus Di Rumah Sakit Umum Kardinah Kota Tegal.Universitas Diponegoro.

WHO Fact Sheet of Diabetes, 2016. 
Volume 2, Nomor 1, Tahun 2020 Hal 291- 300

WHO. (2015). A Global Brief On

Uric Acid. Geneva world Health

Organization. Diabetes

Programme.Accessedat:

https://www.who.int/diabetes/action onli

ne/basics/en/index1.html. 